\title{
Compensatory growth in broilers following water restriction
}

\author{
Ewa Kapkowska ${ }^{1}$ and R.W. Gerry ${ }^{2}$ \\ 'Department of Cattle Breeding, Poultry Section, Krakow' \\ Academy of Agriculture. \\ Al. Mickiewicza 24/28, 30-059 Kraków, Poland \\ 2 Prof. emeritus, Department of Animal and Veterinary Sciences, \\ University of Maine \\ Orono, Maine 04473, USA
}

(Received 19 August 1994; accepted 16 February 1995)

\begin{abstract}
The effects of timing (from 2 days to 6 weeks of age) and duration ( $1-5$ weeks) of restricted water intake on compensatory growth of broilers were studied. In the water restricted groups access to water was limited to three 15-minute periods per day, at 07:00, 12:00 and 17:00 h.

If water was restricted for 1 to 3 weeks, the chicks were able to compensate later for body weight losses. If restriction lasted for 4 or 5 wecks, the chicks did not fully compensate. A onc week-period of water restriction imposed during the first 3 weeks of age decreased the body weight of chickens significantly, which was later compensated. The same period of restriction imposed between the third and sixth weeks of age had no effect on the body weight of chickens.
\end{abstract}

KEY WORDS: broilers, water restriction, compensatory growth

\section{INTRODUCTION}

The ability of animals to compensate for a period of growth retardation has been studied by many authors. Some of the main factors affecting the ability of animals to recover from growth depression are severity, duration and the age at the commencement of restriction. Various programs of undernutrition have been the most common forms of restiction (Auckland and Morris, $1971 \mathrm{a}, \mathrm{b}$; Washburn, 1977; Washburn and Bondari, 1978; Marks, 1978, 1979). Recently new papers have appeared concerning compensatory growth in broilers (Plavnik and Hurwitz, 1985, 1988, 1989; Ślósarz and Kapkowska, 1988; Ballay et al., 1992; Lesson et al., 1992; Plavnik and Balnave, 1992; Roth et al., 1993). 
Some authors recommend feed restriction. Early-life feed restriction programs, designed to decrease body fat and improve feed efficiency in broiler chickens, rely on the phenomenon of compensatory growth to achieve final body weights equivalent to those of broilers fed ad libitum. After a period of severe feed restriction in one-week-old broilers, Plavnik and Hurwitz (1985) observed accelerated growth, responsible for almost complete recovery of body weight at market age. Fontana et al. (1992) stated that broilers were not able to fully compensate in growth when severe feed restriction was imposed early in life.

In view of the inconsistencies reported above, two experiments were conducted to examine further the phenomena of compensatory growth in broilers. Water was the restrictive agent used in these experiments. The role of water, a very important nutrient has usually been overlooked. Marks (1980) suggests that it is possible that appetite in its fullest sense is a composite of both feed and water intake instead of feed intake alone. Gerry (1980), Marks (1980) and Marks and Brody (1984) have studied the influence of water restriction on body weight of broilers, and, conversely, Pinchasov et al. (1984) have investigated the effect of feed restriction in meat type chicks on water intake.

The purpose of this study was to define the influence of water restriction on growth retardation and estimate the ability of broilers to compensate for it.

\section{MATERIAL AND METHODS}

This study was carried out in the experimental farm of the University of Maine. Two experiments were conducted using broilers of a commercial strain. The chickens were housed in environmentally controlled rooms in a battery brooder up to 4 weeks and in rearing batteries from 4 to 7 weeks.

Experiment 1 was conducted to study the compensatory growth of broilers following water restriction for one, two, three, four or five weeks, beginning with one-week-old chickens. There were 6 treatments, each treatment was replicated four times with 10 birds per cage.

In Experiment 2, a one-week period of water restriction at various ages of chickens was imposed. Seven treatments, each with four replications, were used with 10 birds per cage. Both experiments were carried out simultaneously using one common control group. For experimental design see Table 1.

During periods of water restriction in both experiments, water access was limited to three 15-minute periods per day, at 07:00, 12:00 and 17:00 h. After the period of restriction chicks were returned to ad libitum water supply. All birds were provided with ad libitum access to starter diet to 28 days and finisher diet from 29 to 49 days of life (Table 2). The room was lighted from 07:00 to 19:00 h. 
TABLE 1

Water access during consecutive wecks of chickens life

\begin{tabular}{cccc}
\hline & Unlimited & Restricted & Unlimited \\
\hline Experiment 1 & Unlimited & throughout & experiment \\
Treatment 1 & 1 & 2 & $3-7$ \\
2 & 1 & $2-3$ & $4-7$ \\
3 & 1 & $2-4$ & $5-7$ \\
4 & 1 & $2-5$ & $6-7$ \\
5 & 1 & $2-6$ & 7 \\
6 & & & \\
Experiment 2 & Unlimited & throughout & experiment \\
Treatment 1 & - & $2 d-1$ & $2-7$ \\
2 & $0-1$ & 2 & $3-7$ \\
3 & $1-2$ & 3 & $4-7$ \\
4 & $1-3$ & 4 & $5-7$ \\
5 & $1-4$ & 5 & $6-7$ \\
6 & $1-5$ & 6 & 7 \\
7 & & &
\end{tabular}

TABLE 2

Diet composition, \%

\begin{tabular}{lcc}
\hline Ingredients & Starter & Finisher \\
\hline Ground maize & 54.02 & 60.48 \\
Soyabean meal (48\% CP) & 29.20 & 19.80 \\
Luccrne mcal & - & 1.25 \\
Fish meal & 2.50 & 2.50 \\
Meat-and-bone meal & 2.50 & 2.50 \\
Maize gluten meal & 2.50 & 3.75 \\
DL-Methionine & 0.04 & - \\
Dicalcium phosphate & 0.50 & 0.45 \\
Limestone & 0.80 & 0.70 \\
Vitamin mix & 1.00 & 1.00 \\
Mineral mix & 0.58 & 0.58 \\
lodized salt & 0.35 & 0.35 \\
Stabilized fat & 5.75 & 6.30 \\
Choline chloride & 0.26 & 0.34 \\
\hline Calculated composition: & & \\
Crude protein, g/kg & 240.8 & 209.9 \\
Metabolizable energy, $\mathrm{kcal} / \mathrm{kg}$ & 3219 & 3302 \\
Lysine, g/kg & 12.1 & 8.7 \\
Methionine + cystinc, g/kg & 8.7 & 6.7 \\
Available phosphorus, g/kg & 4.2 & 4.1 \\
\hline
\end{tabular}

a - supplied per kg of diet: vitamin A. 12000 lU; vitamin $D_{3}, 3000$ ICU; vitamin E. 37.5 IU; riboflavin, $10 \mathrm{mg}$; pantothenic acid, $20 \mathrm{mg}$; choline, $2 \mathrm{~g}$; niacin, $100 \mathrm{mg}$; thiamine, $10 \mathrm{mg}$; pyridoxine. $10 \mathrm{mg}$; vitamin $\mathrm{K} .1 .5 \mathrm{mg}$; vitamin $\mathrm{B}_{12}, 100 \mathrm{mcg}$; folic acid. $2 \mathrm{mg}$ and ethoxyquin, $150 \mathrm{mg}$

b- supplied per kg of diet: $\mathrm{Mn}, 100 \mathrm{mg}$; Fe, $100 \mathrm{mg}$; Cu, $10 \mathrm{mg}$; Co.1 mg; I, $1 \mathrm{mg} ; \mathrm{Zn}, 100 \mathrm{mg}$ 
Birds were weighed individually at weekly intervals. Feed intake was recorded weekly for each cage, water intake on a daily basis.

Two-way analysis of variance with interaction for data concerning body weight was conducted, the main factors were sex and treatment (Harvey, 1990).

\section{RESULTS}

\section{Experiment 1}

Control birds with unlimited access to water consumed at consecutive weeks of age $27,68,116,159,209,235$ and $255 \mathrm{~g}$ of water per day, per chick, respectively. Water/feed intake ratio in respective weeks was $2.0,1.9,2.0,2.0,2.0$, 1.6 and 1.9 .

Water-restricted chicks in the first week of restriction drank about $20-28 \%$ less than controls, however, with each successive week their water intake increased. Body weights of chicks after one week of water restriction were significantly $(P \leqslant 0.01)$ lower in all groups (Table 3$)$ except group 4 . The withdrawal of water restriction after one weck resulted in an increase in body weights almost up to the level of the control group. Chicks from groups 3 and 4 , water-restricted for 2 or 3 wecks, needed a longer period of time ( 2 weeks) to attain similar body weights as the controls. If water restriction was extended to 4 or 5 weeks, the body weight of chicks at the end of experiment was significantly $(\mathrm{P} \leqslant 0.01)$ lower than in the control group. Interaction between the main effects was not significant, sex differences were significant in all treatments.

Weight gains (Fig. 1) throughout the period of water restriction were significantly $(\mathrm{P} \leqslant 0.01)$ lower than in the control group. After reintroducing water ad libitum the weight gains were slightly higher than in the controls, however, significantly higher only in group 5 .

Water restriction resulted in a decrease in feed intake by $13-20 \%$ in the first week, by $14 \%$ after $2-4$ weeks and by only $6 \%$ after 5 weeks of restriction compared to birds watered ad libitum. After the withdrawal of water restriction feed intake in the experimental groups was similar to that in the control group.

Throughout 7 weeks of the experiment, only birds from groups 5 and 6 consumed significantly less feed than the controls. Feed efficiency during that time was slightly better in restricted birds but no statistical difference was found. Statistical evaluation of feed consumption and feed efficiency data is presented in Table 5, but those data should be taken with caution, since only four replications in each group were made and the sex ratio in groups was not equalized. 


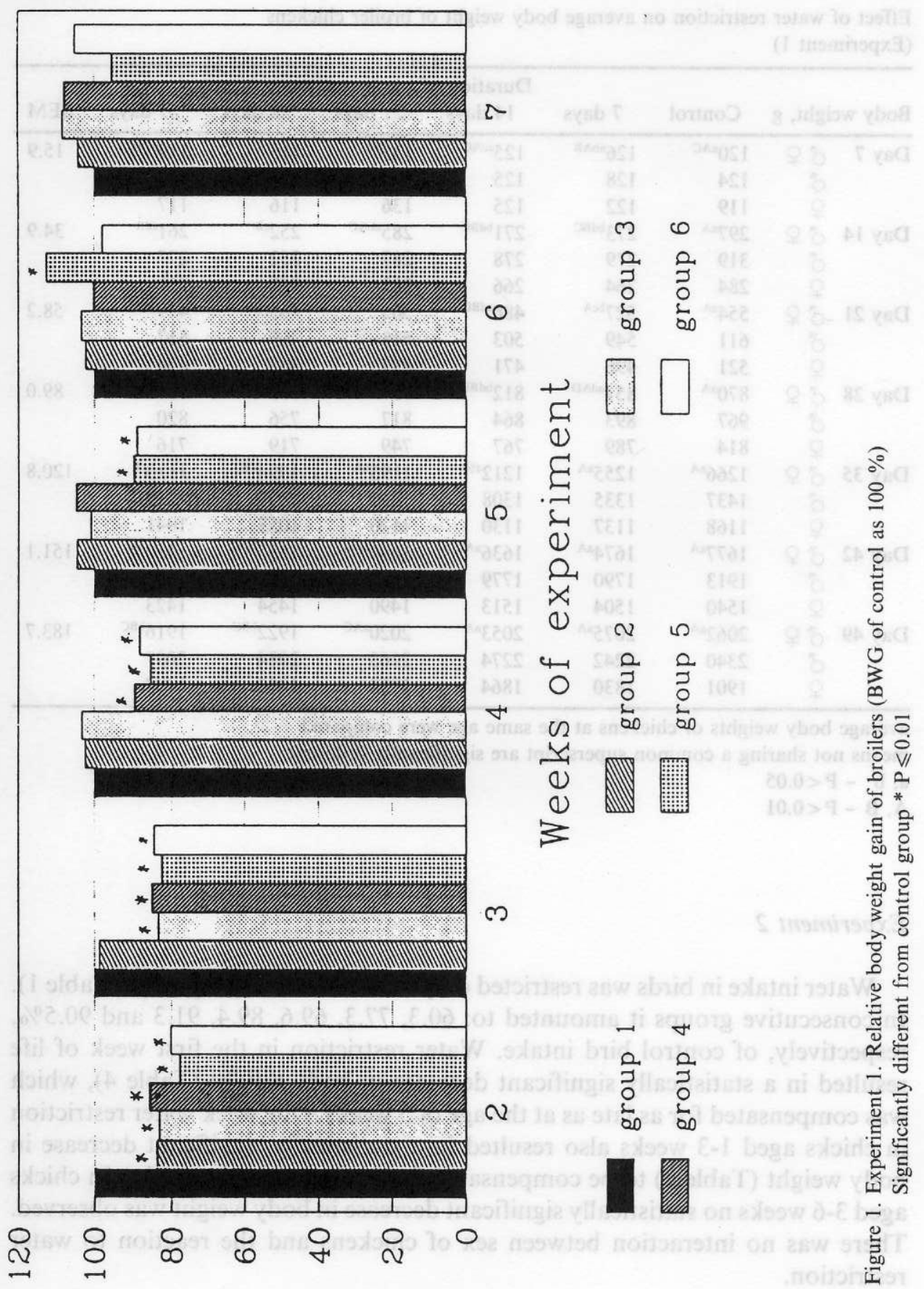


TABLE 3

Effect of water restriction on average body weight of broiler chickens

(Experiment 1)

\begin{tabular}{|c|c|c|c|c|c|c|c|c|}
\hline \multirow{2}{*}{\multicolumn{2}{|c|}{ Body weight }} & \multicolumn{7}{|c|}{ Duration of water restriction } \\
\hline & & \multirow{2}{*}{$\frac{\text { Control }}{120^{\mathrm{aAC}}}$} & \multirow{2}{*}{$\frac{7 \text { days }}{126^{\mathrm{abAB}}}$} & \multirow{2}{*}{$\frac{14 \text { days }}{125^{\text {acAC }}}$} & \multirow{2}{*}{$\frac{21 \text { days }}{135^{\text {bB }}}$} & \multirow{2}{*}{$\frac{28 \text { days }}{115^{\mathrm{CC}}}$} & \multirow{2}{*}{$\frac{35 \text { days }}{119^{\text {acAC }}}$} & \multirow{2}{*}{$\frac{\text { SEM }}{15.9}$} \\
\hline Day 7 & $\pi$ ㅇ & & & & & & & \\
\hline & 8 & 124 & 128 & 125 & 133 & 114 & 122 & \\
\hline & Q & 119 & 122 & 125 & 136 & 116 & 117 & \\
\hline \multirow[t]{3}{*}{ Day 14} & oq & $297^{\mathrm{aA}}$ & $273^{\text {hdBC }}$ & $271^{\text {buBC }}$ & $285^{\mathrm{abAC}}$ & $252^{\text {cI }}$ & $261^{\mathrm{cdB}}$ & 34.9 \\
\hline & $\delta^{x}$ & 319 & 279 & 278 & 287 & 252 & 277 & \\
\hline & Q & 284 & 264 & 266 & 283 & 253 & 251 & \\
\hline \multirow[t]{3}{*}{ Day 21} & dq & $554^{\mathrm{aA}}$ & $527^{\mathrm{bcA}}$ & $486^{\mathrm{cdAD}}$ & $505^{\mathrm{bd} H C}$ & $465^{\mathrm{cD}}$ & $479^{\mathrm{CdBD}}$ & 58.2 \\
\hline & $0^{+}$ & 611 & 549 & 503 & 518 & 469 & 517 & \\
\hline & q & 521 & 496 & 471 & 487 & 462 & 454 & \\
\hline \multirow[t]{3}{*}{ Day 28} & do & $870^{a A}$ & $851^{\text {adAD }}$ & $812^{\mathrm{DdBD}}$ & $787^{\mathrm{bBC}}$ & $735^{\mathrm{cC}}$ & $757^{\circ \mathrm{C}}$ & 89.0 \\
\hline & 8 & 967 & 893 & 864 & 817 & 756 & 820 & \\
\hline & 우 & 814 & 789 & 767 & 749 & 719 & 716 & \\
\hline \multirow[t]{3}{*}{ Day 35} & d우 & $1266^{\mathrm{aA}}$ & $1255^{\mathrm{aA}}$ & $1212^{\mathrm{abA}}$ & $1193^{\mathrm{bA}}$ & $1094^{\mathrm{CB}}$ & $1110^{\mathrm{cB}}$ & 120.8 \\
\hline & 8 & 1437 & 1335 & 1308 & 1250 & 1149 & 1212 & \\
\hline & 0 & 1168 & 1137 & 1130 & 1120 & 1053 & 1041 & \\
\hline \multirow[t]{3}{*}{ Day 42} & OP & $1677^{\mathrm{aA}}$ & $1674^{0 \wedge}$ & $1636^{\mathrm{AAC}}$ & $1604^{\mathrm{acAC}}$ & $1555^{\mathrm{bcBC}}$ & $1510^{\mathrm{bB}}$ & 151.1 \\
\hline & 8 & 1913 & 1790 & 1779 & 1692 & 1692 & 1642 & \\
\hline & 9 & 1540 & 1504 & 1513 & 1490 & 1454 & 1423 & \\
\hline \multirow[t]{3}{*}{ Day 49} & o오 & $2062^{\mathrm{aA}}$ & $2075^{\mathrm{aA}}$ & $2053^{\mathrm{aA}}$ & $2020^{\mathrm{aAC}}$ & $1922^{\mathrm{tBC}}$ & $1916^{\mathrm{hBC}}$ & 183.7 \\
\hline & $0^{+}$ & 2340 & 2242 & 2274 & 2163 & 2084 & 2097 & \\
\hline & 9 & 1901 & 1830 & 1864 & 1834 & 1803 & 1794 & \\
\hline
\end{tabular}

average body weights of chickens at the same age were compared means not sharing a common superscript are significantly different

$\mathrm{a}, \mathrm{b}-\mathrm{P}<0.05$

A, B $-\mathbf{P}<0.01$

\section{Experiment 2}

Water intake in birds was restricted only for one week in all groups (Table 1). In consecutive groups it amounted to: $60.3,77.3,69.6,89.4,91.3$ and $90.5 \%$, respectively, of control bird intake. Water restriction in the first week of life resulted in a statistically significant decrease in body weight (Table 4), which was compensated for as late as at the age of 5 weeks. One week water restriction in chicks aged 1-3 weeks also resulted in a statistically significant decrease in body weight (Table 4) to be compensated for in the following weeks. In chicks aged 3-6 weeks no statistically significant decrease in body weight was observed. There was no interaction between sex of chickens and the reaction to water restriction. 
TABLE 4

Effect of water restriction lasting one week on average body weight of broiler chickens (Experiment 2)

\begin{tabular}{|c|c|c|c|c|c|c|c|c|c|}
\hline \multirow{2}{*}{\multicolumn{2}{|c|}{ Body wcight, g }} & \multicolumn{8}{|c|}{ Age al beginning of restriction } \\
\hline & & \multirow{2}{*}{$\frac{\text { Control }}{120^{\mathrm{aA}}}$} & \multirow{2}{*}{$\frac{5 \text { days }}{98^{\text {bB }}}$} & \multirow{2}{*}{$\frac{7 \text { days }}{126^{\mathrm{acA}}}$} & \multirow{2}{*}{$\frac{14 \text { days }}{126^{\text {acA }}}$} & \multirow{2}{*}{$\frac{21 \text { days }}{121^{\text {aA }}}$} & \multirow{2}{*}{$\frac{28 \text { days }}{129^{\text {cA }}}$} & \multirow{2}{*}{$\frac{35 \text { days }}{129^{\mathrm{cA}}}$} & \multirow{2}{*}{$\begin{array}{r}\text { SEM } \\
15.0\end{array}$} \\
\hline Day 7 & $\theta q$ & & & & & & & & \\
\hline & 8 & 124 & 101 & 128 & 126 & 122 & 130 & 125 & \\
\hline & 9 & 119 & 96 & 122 & 126 & 119 & 128 & 131 & \\
\hline \multirow[t]{3}{*}{ Day 14} & $\delta$ & $297^{\mathrm{A}}$ & $261^{B}$ & $273^{B}$ & $302^{A}$ & $299^{A}$ & $313^{A}$ & $308^{\mathrm{A}}$ & 36.4 \\
\hline & 8 & 319 & 268 & 279 & 306 & 306 & 317 & 307 & \\
\hline & 9 & 284 & 250 & 264 & 299 & 288 & 310 & 308 & \\
\hline \multirow[t]{3}{*}{ Day 21} & 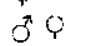 & $554^{\text {acAB }}$ & $517^{\mathrm{bA}}$ & $527^{\mathrm{abAB}}$ & $519^{\mathrm{bA}}$ & $563^{\mathrm{EdAC}}$ & $587^{\mathrm{dC}}$ & $565^{\mathrm{CdBC}}$ & 59.7 \\
\hline & 3 & 611 & 543 & 549 & 531 & 578 & 610 & 571 & \\
\hline & $?$ & 521 & 481 & 496 & 505 & 535 & 565 & 562 & \\
\hline \multirow[t]{3}{*}{ Day 28} & 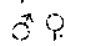 & $870^{\mathrm{aAA}}$ & $823^{\mathrm{bA}}$ & $851^{\text {abAC }}$ & $852^{\mathrm{abAC}}$ & $840^{: \mathrm{bac}}$ & $914^{\mathrm{cB}}$ & $883^{\mathrm{acBC}}$ & 92.4 \\
\hline & 3 & 967 & 871 & 893 & 883 & 866 & 965 & 914 & \\
\hline & 0 & 814 & 757 & 789 & 817 & 794 & 866 & 863 & \\
\hline \multirow[t]{3}{*}{ Day 35} & $\theta^{x}+$ & $1267^{\mathrm{ab}}$ & $1215^{\prime \prime}$ & $1255^{\mathrm{ib}}$ & $1245^{\mathrm{ab}}$ & $1236^{\mathrm{ab}}$ & $1287^{b}$ & $1261^{\mathrm{ab}}$ & 124.9 \\
\hline & 2 & 1437 & 1296 & 1335 & 1298 & 1278 & 1366 & 1317 & \\
\hline & \% & 1168 & 1101 & 1137 & 1184 & 1156 & 1213 & 1225 & \\
\hline \multirow[t]{3}{*}{ Day 42} & d? & $1677^{\mathrm{Als}}$ & $1651^{\mathrm{AH}}$ & $1674^{A B}$ & $1655^{\wedge \mathrm{B}}$ & $1676^{\mathrm{AB}}$ & $1730^{\mathrm{A}}$ & $1614^{13}$ & 165.7 \\
\hline & d & 1913 & 1779 & 1790 & 1730 & 1746 & 1849 & 1700 & \\
\hline & q & 1540 & 1471 & 1504 & 1570 & 1546 & 1618 & 1558 & \\
\hline \multirow[t]{3}{*}{ Day 49} & 09 & $2062^{\mathrm{AB}}$ & $2028^{\wedge B}$ & $2075^{\wedge \mathrm{A}}$ & $2029^{A \mathrm{~B}}$ & $2054^{\wedge B}$ & $2123^{\wedge}$ & $1982^{B}$ & 207.3 \\
\hline & $\sigma^{2}$ & 2340 & 2189 & 2242 & 2127 & 2170 & 2279 & 2111 & \\
\hline & 3 & 1901 & 1802 & 1830 & 1916 & 1841 & 1975 & 1900 & \\
\hline
\end{tabular}

average body wcights of chickens at the same age were compared a, b, A, B - as in Table 3

Water restriction beginning with 2-day-old chickens (group 2) had the most adverse effect on feed intake. The lower feed intake in this group was maintained even after the withdrawal of water restriction. Also in groups 3, 4, and 5 a significant decrease in feed intake during the period of water restriction was found. One week water restriction in chicks older than 5 weeks did not decrease feed intake significantly. Cumulative feed intake as well as feed efficiency for 7 weeks were slightly better in all restricted groups but the differences were not statistically significant.

\section{DISCUSSION}

Water intake by control birds was similar to that reported by Marks (1980) and slightly higher than that found by Kapkowska (1980). It was recognized 
that many factors might affect water intake, among others the genetic origin of the chickens, their growth rate, source and concentration of dietary protein, physical form of diet and ambient temperature (Kapkowska, 1980; Marks, 1980; Marks and Brody, 1984).

No statistically significant effect of water restriction on body weight was found in 3-6 week-old chicks. The results of Gerry (1980) indicate that between the fifth to eighth week of age the time of water availability could be reduced to 15 min per hour without adverse effect on performance of broilers in cages.

Compensatory growth in broilers is a complex and still not fully understood phenomenon, producing varied responses to different restriction programs. A primary objective of this study was to define the extent of compensatory growth under conditions of water restriction which consequently caused reduced feed intake. Pinchasov et al. (1987) found a high positive correlation between water and feed intake. In the experiment of Proudman and Opel (1981) feed restriction and water restriction were equally effective in limiting the growth of young turkey poults. There have been several studies on the effect of restricted length of feeding time on the growth of broilers and feed consumption. McCartney and Brown (1977) reported that growth in broiler males was not adversely affected by limiting the feeding time by as much as 15 min each two hours, however, the same feeding time in each three or four hours did result in a significant decrease in body weight.

In our experiment, if the water restriction period lasted for $1-3$ weeks beginning with one-week-old birds, chickens could compensate for the decrease in body weight up to 49 days of age. This also applies to chicks up to three weeks of age, water-restricted for one week only. These findings are in agreement with those of Plavnik and Hurwitz (1988, 1989, 1991), Plavnik et al. (1986), Jones and Farrell (1992 a,b), Zubair and Lesson (1994), who reported compensatory growth in broilers following early feed restriction. Other investigators (Mollison et al., 1984; Pinchasov and Jansen, 1989) have observed significantly lower body weights but improved feed efficiency in feed restricted broilers when compared with ad libitum controls at various market ages.

With water restriction lasting for 4-5 weeks the broilers did not compensate fully for body mass losses, which indicates that a period of 2-3 weeks of unrestricted water supply at the end of the fattening periods is too short for full body weight recovery.

In both experiments broiler males were more sensitive than females to water restriction and they displayed slower compensatory growth. Slósarz and Kapkowska (1988) have observed a similar phenomenon with respect to feed restriction in broilers.

In summary, feed restriction in broilers is worth recommending, but should be started at an early age in order to leave the birds enough recovery period for 
Effect of duration of water restriction on average feed intake (g/week)

(Experiment 1)

\begin{tabular}{|c|c|c|c|c|c|c|c|c|c|c|}
\hline \multirow[t]{2}{*}{ Group } & \multirow{2}{*}{$\begin{array}{c}\text { Duration } \\
\text { of water } \\
\text { restriction, } \\
\text { days }\end{array}$} & \multicolumn{8}{|c|}{ Weeks of age } & \multirow{2}{*}{$\begin{array}{c}\mathrm{g} \text { feed } \\
\text { per } \\
\mathrm{g} \mathrm{BW}\end{array}$} \\
\hline & & 1 & 2 & 3 & 4 & 5 & 6 & 7 & $0-7$ & \\
\hline Control & & 94 & 248 & 401 & 554 & 748 & 1101 & 931 & 4075 & 2.26 \\
\hline 2 & 7 & 99 & 206 & 377 & 579 & 696 & 1079 & 927 & 3964 & 1.96 \\
\hline 3 & 14 & 100 & 205 & $337^{\mathrm{xx}}$ & 548 & 717 & 1071 & 913 & 3890 & 1.93 \\
\hline 4 & 21 & 107 & 217 & $346^{x}$ & $481^{\mathrm{x} x}$ & 719 & 1084 & 951 & 3905 & 1.98 \\
\hline 5 & 28 & 87 & 207 & $334^{x x}$ & $476^{x x}$ & $649^{x}$ & 1082 & 953 & $3789^{x}$ & 2.02 \\
\hline 6 & 35 & 94 & $196^{x x}$ & $326^{x x}$ & $479^{\mathrm{xx}}$ & $625^{x x}$ & 1035 & 919 & $3698^{\mathrm{xx}}$ & 1.96 \\
\hline
\end{tabular}

TABLE 6

Effect of water restriction imposed at various age on average feed intake (g/week)

(Experiment 2)

\begin{tabular}{|c|c|c|c|c|c|c|c|c|c|c|}
\hline \multirow[t]{2}{*}{ Group } & \multirow{2}{*}{$\begin{array}{c}\text { Age at } \\
\text { beginning } \\
\text { of water } \\
\text { restriction. } \\
\text { days }\end{array}$} & \multicolumn{8}{|c|}{ Weeks of age } & \multirow{2}{*}{$\begin{array}{c}\mathrm{g} \text { feed } \\
\text { per } \\
\mathrm{g} \mathrm{BW}\end{array}$} \\
\hline & & 1 & 2 & 3 & 4 & 5 & 6 & 7 & $0-7$ & \\
\hline Control & & 94 & 248 & 401 & 554 & 748 & 1101 & 931 & 4075 & 2.26 \\
\hline 2 & 2 & $77^{x x}$ & $211^{x x}$ & 382 & $498^{x}$ & 719 & 1097 & 912 & 3920 & 1.96 \\
\hline 3 & 7 & 99 & $206^{\mathrm{xx}}$ & 377 & 579 & 696 & 1079 & 927 & 3964 & 1.96 \\
\hline 4 & 14 & 98 & 234 & $345^{\mathrm{xx}}$ & 566 & 768 & 1119 & 943 & 4071 & 2.05 \\
\hline 5 & 21 & 94 & 235 & 410 & $499^{x}$ & 710 & 1103 & 951 & 4001 & 1.98 \\
\hline 6 & 28 & 98 & 247 & 422 & 582 & 697 & 1130 & 976 & 4084 & 1.96 \\
\hline 7 & 35 & $97^{x}$ & 242 & 412 & 551 & 698 & 1055 & 949 & 4004 & 2.04 \\
\hline
\end{tabular}

$\mathrm{x}-\mathrm{P}<0.05$

$\mathrm{xx}-\mathrm{P}<0.01$, statistically different from control group

manifesting compensatory growth, which is in agreement with observations of Plavnik and Hurwitz (1991) and Jones and Farrell (1992a). Feed restriction can be induced through water restriction but this requires much more caution.

The metabolic changes that permit compensatory growth are not fully understood. In the experiment of Proudman and Opel (1981) both feed and water restriction of growing turkeys resulted in an increase of plasma growth hormone (GH) level which remained elevated above control levels after returning to ad libilum intake. This may partially explain the compensatory growth phenomenon. 


\section{REFERENCES}

Auckland J.N., Morris T.R., 1971a. Compensatory growth in turkeys: Effect of undernutrition on subsequent protein requirements. Brit. Poultry Sci. 12, 41-48

Auckland J.N., Morris T.R., 1971 b. Compensatory growth after undernutrition in market turkeys: Effect of low protein feeding and realimentation on body composition. Brit. Poultry Sci. 12, $137-150$

Ballay M., Dunnington E.A., Gross W.B., Siegel P.B., 1992. Restricted feeding and broiler performance: age at initiation and length of restriction. Poultry Sci. 71, 440-447

Fontana E.A., Weaver W.D. Jr., Watkins B.A., Denbow D.M., 1992. Effect of early feed restriction on growth, feed conversion, and mortality in broiler chickens. Poultry Sci. 71, 1296-1305

Gerry P., 1980. Effects of the restriction of time of water availability on the performance of cage reared broilers. Poultry Sci. 59, 211-214

Harvey W., 1990. User's Guide for LSMLMW and MIXMDL PC-2 version

Jones G.P.D., Farrell D.J., 1992a. Early-life food restriction of broiler chickens. I. Methods of application, amino acid supplementation and the age at which restriction should commence. Brit. Poultry Sci. 33, 579-587

Jones G.P.D., Farrell D.J., 1992b. Early-life food restriction of broiler chickens. II. Effects of food restrictions on the development of fat tissue. Brit. Poultry Sci. 33, 589-601

Kapkowska E., 1980. The effect of water intake on growth and nitrogen utilization in broiler chickens (in Polish). Rocz. Nauk. Rol. Ser. B, 100, 7-21

Lesson S., Summers J.D., Caston L.J., 1992. Response of broilers to feed restriction or diet dilution in the finisher period. Poultry Sci. 71, 2056-2064

Marks H.L., 1978. Compensatory growth in Japanese quail following protein restriction. Poultry Sci. $57,1473-1477$

Marks H.L., 1979. Compensatory growth of selected and nonselected broilers following early protein restriction. Poultry Sci. 58, 1409-1414

Marks H. L., 1980. Water and feed intake of selected and nonselected broilers under ad libitum and restricted feeding regimes. Growth 14, 205-219

Marks H.L., Brody T., 1984. Intakes of feed and water following restriction in selected and nonselected broilers. Poultry Sci. 63, 2307-2317

MaCartney M.G., Brown H.B., 1977. Effects of feed restriction time on the growth and feed consumption of broiler males. Poultry Sci. 56, 713-715

Mollison B., Guenter W., Boycott B.R., 1984. Abdominal fat deposition and sudden death syndrome in broilers: the effects of restricted intake, early life caloric (fat) restriction, and calorie: protein ratio. Poultry Sci. 63, 1190-1200

Pinchasov Y., Jensen L.S., 1989. Comparison of physical and chemical means of feed restriction in broiler chicks. Poultry Sci. 68, 61-69

Pinchasov Y., Nir I.. Zafrira Nitsan, 1987. Water intake and water concentration in the body and gastrointestinal tract of intermittently fed broiler chickens. Brit. Poultry Sci. 28, 287-294

Plavnik I., Balnave D., 1992. Responses of different strains of Australian broiler chickens to feed restriction at an carly age. Aust. J. Agric. Res. 43, 1253-1258

Plavnik I., Hurwitz S., 1985. The performance of broiler chicks during and following a severe feed restriction at an early age. Poultry Sci. 64, 348-355

Plavnik I., Hurwitz S., 1988. Early feed restriction in chicks: effect of age, duration, and sex. Poultry Sci. $67,384-390$

Plavnik I., Hurwitz S., 1989. Effect of dietary protein, energy and feed pelleting on the response of chick to early feed restriction. Poultry Sci. $68,1118-1125$ 
Plavnik I., Hurwitz S., 1991. Response of broiler chickens and turkey poults to food restriction of varicd scverity during early life. Brit. Poultry Sci. 32, 343-352

Plavnik I., McMurtry J.P., Rosebrough R.W., 1986. Effects of early feed restriction in broilers. I. Growth performance and carcass composition. Growth 50, 68-76

Proudman J.A., Opel H., 1981. Effect of feed or water restriction on basal and TRH-stimulated growth hormone secretion in the growing turkey poult. Poultry Sci. 60, 659-667

Roth F.X., Kirchgessner M., Windisch W., 1993. Compensatory growth of broilers: Effect of feed restriction,varying in severity, duration and onset. Arch. Geflügelk. 57, 1-8

Ślósarz A., Kapkowska E., 1988. Compensatory growth of broilers under conditions of quantitative feed restriction (in Polish). Acta Agr. Silv. Ser. zoot. 27, 113-125

Washburn K.W., Bondari K., 1977. Comparison of effects of severity and duration of restricted feeding on growth, feed consumption and feed conversion of broiler chicks grown in individual cages and floor pens. Arch. Geflügelk. 42, 94-98

Washburn K.W., Bondari K., 1978. Effects of timing and duration of restricted feeding on compensatory growth in broilers. Poultry Sci. 57, 1013-1021

Zubair A.K., Lesson S., 1994. Effect of varying period of early nutrient restriction on growth compensation and carcass characteristics of male broilers. Poultry Sci. 73, 129-136

\section{STRESZCZENIE}

\section{Wzrost kompensacyjny u brojlerów w warunkach ograniczenia dostępu do wody}

Badano wpływ terminu rozpoczęcia ograniczania wody (od 2 dnia życia do 6 tygodnia) i czasu trwania ograniczenia ( $1-5$ tygodni) na zjawisko wzrostu kompensacyjnego u brojlerów. $W$ grupach doświadczalnych dostęp do poideł byl ograniczony do trzech 15-minutowych okresów w ciągu dnia o 7:00, 12:00 i 17:00. W przypadku ograniczania dostępu do wody od 1 do 3 tygodni kurczęta kompensowaly straty masy ciala. Nie stwierdzono pełnej kompensacji wzrostu w przypadku ograniczenia dostępu do wody przez 4 lub 5 tygodni. Ograniczenie dostępu do wody przez 1 tydzień w ciągu pierwszych 3 tygodni życia powodowało obniżenie masy ciała, ale ptaki straty te kompensowaly przed końcem tuczu; taki sam okres ograniczenia dostępu do wody u kurcząt starszych nie wplywal na przyrost masy ciała. 